\title{
ДІДЖЕТАЛІЗАЦІЯ ОСВІТИ
}

УДК 372.8:377.1(045):004

DOI 10.25128/2415-3605.19.2.17

\author{
СЕРГІЙ ЄВСТРАТ’ЄВ \\ ID ORCID:0000-0003-0132-3410 \\ sergejevstratjev@gmail.com \\ аспірант \\ м. Київ, вул. Смілянська, 11
}

Національний університет біоресурсів і природокористування України

\section{ДІДЖИТАЛІЗАЦІЯ АГРАРНОЇ ОСВІТИ І АНАЛІЗ ВПРОВАДЖЕННЯ РЕЗУЛЬТАТІВ МІЖНАРОДНИХ ОСВІТНІХ ПРОСКТІВ}

Розглянуто прочес діджиталізаиї сучасної аграрної освіти під впливом прочесу глобальноі комп'ютеризаціїі $i$ вимог сучасного інформаційного суспільства. Наведено приклади сучасних комп'ютерних VR-технологій, які вже сьогодні використовують в агровиробництві. Наведено схему реалізаиії міжнародного досвіду в українських закладах вищої освіти (ЗВО) завдяки участі у міжнародних освітніх проєктах. Представлено опис міжнародних проєктів, щяо їх виконують $3 В О$ аграрного профілю, перераховано партнерів. Наведено елементи Е-навчання, які впроваджують в освітній процес за результатами роботи проєктів, зокрема заходи, спрямовані на підвищення якості освітніх послуг і кваліфікації викладачів: серії тренінгів, пов'язаних зі сучасними методиками викладання в аграрній освіті, практичні семінари для викладачів і студентів, навчальні поїздки за кордон для ознайомлення з системою аграрної освіти $i$ базами практичного навчання. Представлено структурну модель функціонування електронної платформи знань з органічного виробницва, описано складові платформи для забезпечення освітньої діяльності в галузі органічного виробництва в Украӥні. Описано функціонал модулів платформи, взаємодію між ними, а також інструментарій для забезпечення підвищення кваліфікачї викладацького складу аграрних ЗВО, формування циифрових компетенцій шляхом запровадження освітньої дисиипліни «Діджиталізація у сільському господарстві», створення сучасних електронних навчальних матеріалів, електронних курсів.

Ключові слова: інформаційно-комунікаційні технологї, електронна платформа знань, рівень освітніх послуг, міжнародні освітні проєкти, підвищення кваліфікації, репозитарій, інформащійний ресурс, пошук інформації.

\section{СЕРГЕЙ ЕВСТРАТЬЕВ}

аспирант

Национальный университет биоресурсов и природоиспользования Украины

г. Киев, ул. Смелянская, 11

\section{ДИДЖИТАЛИЗАЦИЯ АГРАРНОГО ОБРАЗОВАНИЯ И АНАЛИЗ ВНЕДРЕНИЯ РЕЗУЛЬТАТОВ МЕЖДУНАРОДНЫХ ОБРАЗОВАТЕЛЬНЫХ ПРОЕКТОВ}

Рассмотрен прочесс диджитализачии современного аграрного образования под влиянием процесса глобальной компьютеризации и требований современного информационного общества. Приведены примеры современных компьютерных VR-технологий, которые уже сегодня используют 8 агропроизводстве. Приведена схема реализачии международного опыта в украинских вузах благодаря участию в международных образовательных проектах. Представлено описание международных проектов, которые выполняют вузы аграрного профиля, перечислены партнеры. Приведены элементьл Е-обучения, которые внедряют в образовательный прочесс по результатам работы проектов, в том числе меры, направленные на повышение качества образовательных услуг и квалификации преподавательского состава: серии тренингов, связанные с современными методиками преподавания в аграрном образовании, практические семинары для преподавателей и студентов, учебные поездки за 
гранииу для ознакомления с системой аграрного образования и базами практического обучения. Представлена структурная модель функционирования электронной платформы знаний по органическому производству, описань елементы платформы для обеспечения образовательной деятельности в области органического производства в Украине. Описан функционал модулей платформы, взаимодействие между ними, а также инструментарий для обеспечения повышения квалификации преподавательского состава аграрных высших учебных заведений, формирование иифровых компетенщий путем введения образовательной дисииплинь «Диджитализация в сельском хозяйстве», создание современных электронных учебных материалов, электронных курсов.

Ключевые слова: информационно-коммуникационные технологии, электронная платформа знаний, уровень образовательных услуг, международные образовательныле проекты, повымение квалификачии, репозитарий, информаџионный ресурс, поиск информации.

\section{SERHIY YEVSTRATYEV}

National University of Life and Environmental Sciences of Ukraine Kyiv, 11 Smilyanska Str.

\section{DIGITIZATION OF AGRICULTURAL EDUCATION AND ANALYSIS OF IMPLEMENTATION OF INTERNATIONAL EDUCATIONAL PROJECTS RESULTS}

The international community is actively involved in the problems of creating and using modern e-devices in agricultural education. A specialist has to use modern information technology in his or her practical activity to realize the benefits of technology in any system, It should be noted that digital competence of teachers is an essential prerequisite for effective implementation of modern information technologies into the educational process. The work of international educational projects in agrarian area is focused on improving the methods and content of practical training, teaching and advanced training of already trained specialists. Teachers of agricultural universities and colleges, who study aspects in the fields of agriculture and teach agrarian disciplines are the target groups of the projects. The active participation of educational institutions in the work of the projects contributes to the implementation of modern information and communication technologies, the creation of quality e-resources on its base and the support of training of agricultural specialties. At seminars, trainings organized by projects teachers gain some experience in creating and implementing training materials, also they are involved in the development of quality educational material and the filling of electronic resources. The article discusses the process of digitization of modern agrarian education under the influence of the process of global computerization and the requirements of the modern information society. Here are some examples of modern VR technology that is already being used in agro-industry. The scheme of realization of the international experience in Ukrainian educational institutions through participation in international educational projects is presented. There is a description of international projects implemented by agrarian higher education institutions, partners, and e-learning elements that are implemented in the educational process based on project results, including measures aimed at improving the quality of educational services and teacher qualifications, such as trainings related to modern methods of teaching in agrarian education, practical seminars for teachers and students, study visits abroad to get acquainted with the agrarian education system, practical training bases. The structural model of functioning of the e-platform of knowledge on organic production is presented, the constituents of the platforms for providing educational activity in the field of organic production in Ukraine are described. Functionality of platform modules, interaction between them is described. The toolkit for providing advanced training of the teaching staff of agrarian institutions of higher education, formation of digital competences by introduction of the educational discipline "Dititalization in agriculture", creation of modern electronic educational materials, e-courses are described.

Keywords: information and communication technologies, electronic platform of knowledge, level of educational services, international educational projects, advanced training, repository, information resource, search for information.

Міжнародна спільнота активно опікується проблемами створення i використання сучасних е-засобів в аграрній освіті. Базові навички в галузі інформаційно-комунікаційних технологій (IКТ) полягають у використанні комп'ютерів для пошуку, оцінювання, збереження, виробництва, представлення і обміну інформацією, спілкування та участі в спільнотах мережі інтернет. Для реалізації переваг технологій у будь-якій системі фахівцеві необхідно використовувати сучасні ІКТ у своїй практичній діяльності. Зауважимо, що цифрова 
компетентність викладачів є необхідною умовою для ефективного впровадження сучасних інформаційних технологій в освітній процес.

У звіті Eurydice за 2012 р. зазначено, що майже в усіх європейських країнах існує національна стратегія, пов’язана 3 цифровою компетентністю. Вже тоді у європейську традиційну освіту почали інтегрувати цифрові компетенції міждисциплінарно і як окремий навчальний предмет. Забезпечення викладачів достатнім рівнем цифрової компетенції, а далі, як похідна, і сучасних фахівців, яких вони готують, є сьогодні ключовим чинником подальшого економічного розвитку [1].

Мета статті: проаналізувати досвід впровадження міжнародних освітніх проєктів 3 діджиталізації аграрної освіти в Україні.

Роботу міжнародних освітніх проєктів аграрного напряму зосереджено на поліпшенні методів і змісту практичного навчання, підготовки і підвищення кваліфікації вже підготовлених фахівців. 3-поміж цільових груп у роботі проєктів $є$ викладачі аграрних університетів i коледжів, які досліджують аспекти в галузях сільського господарства та викладають дисципліни аграрного спрямування. Активна участь ЗВО у роботі проєктів частково вирішує проблеми недофінансованості цих закладів для впровадження сучасних IКТ, створення на своїй базі якісних е-ресурсів і супровід навчання аграрних спеціальностей. Отримуючи досвід зі створення i впровадження навчальних матеріалів на семінарах, тренінгах, організованих проєктом, викладачі долучаються до створення якісного навчального матеріалу і наповнення ним електронних ресурсів. Працюючи над завданнями проєктів, вони отримують доступ до новітніх технологій у сільському господарстві, що сприяє їх розвитку як науковців і педагогів. Результати такої роботи впроваджують в освітній процес ЗВО аграрного профілю. Беручи за основу сучасні аграрні IКT, спираючись на європейську освіту i міжнародний досвід, міжнародні освітні агропроєкти підвищують якість освітніх послуг у конкретних 3ВО, допомагаючи як методично, так і фінансово. Результатом є впровадження в освітній процес якісно нових форм і методів навчання. Викладачі, котрі пройшли закордонне стажування, здобувають знання які грунтуються на сучасних технологіях і мають практичну основу (рис. 1).

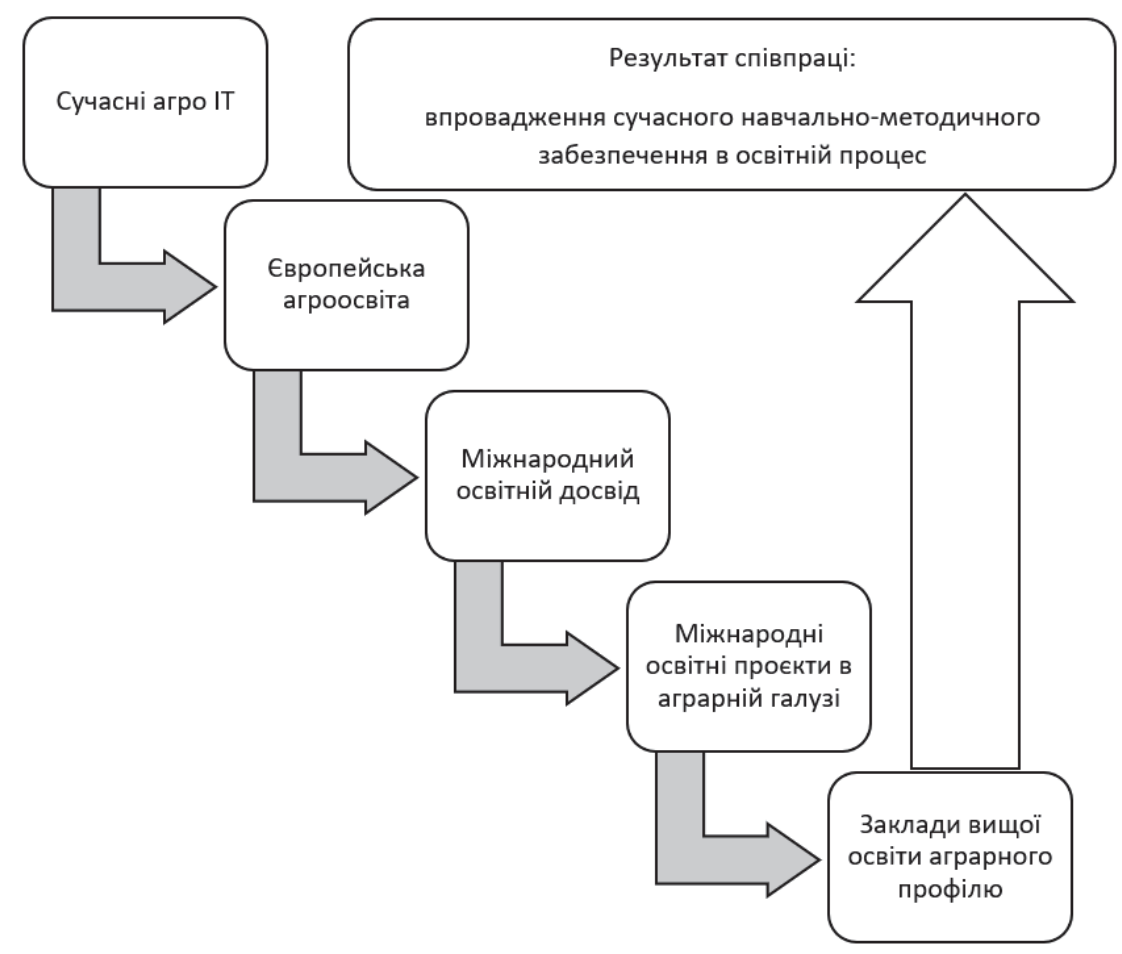

Рис. 1. Схема взаємодії у міжнародних освітніх проєктах.

Процес діджиталізації - сьогодні відоме явище, яке існує практично в усіх сферах людської діяльності. Діджиталізацію освіти висвітлено у великій кількості робіт вітчизняних та зарубіжних вчених, дослідженнях, проведених науковими i комерційними установами. 
Загальний висновок таких досліджень зведено до ідеї, що в найближчому майбутньому роботи на основі штучного інтелекту замінять більшість професій. Д. Топорова стверджує що рівень діджиталізації та автоматизації певних професій досяг рівня 98\% [5, с. 109-116].

А. Шаповаловим відзначає «Діджиталізація освіти - це процес поглинання, застосування та асиміляції інститутом освіти новітніх технологічних розробок на ниві комунікаційних технологій $з$ подальшим використанням їх 3 навчальними, комунікаційними та виховними цілями». Процес діджиталізації у світі йде вже давно, але в Україні зараз це явище набуло значущості. Таким чином, маючи досвід, міжнародні проєкти впроваджують ІКТ в освітній процес [1]. І. Силадій стверджує, що досвід цивілізаційного розвитку найбільш передових країн світу засвідчує вирішальну роль освіти загалом у таких сферах, як модернізація виробництва, вдосконалення суспільних відносин, наука і культура, які забезпечують сталий розвиток суспільства $[4$, с. 34-38].

У суспільстві з інноваційною економікою важливе значення надається «виробництву знань» та працівнику, який застосовує ці знання. А сам працівник, окрім використання набутих знань, безпосередньо бере участь у виробництві нових знань, що підвищує ефективність його діяльності.

За результатами роботи міжнародного проєкту FABU «Сприяння розвитку професійної освіти в аграрних коледжах України», метою якого $€$ поліпшення методів і змісту практичного навчання в таких закладах освіти, забезпечення їх використання учасниками проєкту та запровадження механізмів їх подальшого постійного удосконалення, в чотирьох аграрних коледжах розроблено і підготовлено до затвердження в МОН України навчальні плани, які передбачають формування у здобувачів професійних цифрових компетентностей [3].

Портрет сучасного фахівця будь-якого напряму неодмінно має чіткі математичні i технічні компетенції в ІКТ. Для успішної роботи сучасному фахівцеві недостатньо володіти певним набором специфічних знань, бізнес потребує фахівця, який швидко зможе переорієнтуватися для виконання того чи іншого виробничого завдання. Для забезпечення таких освітніх потреб цікаво буде розглянути німецький досвід упровадження електронної освіти (E-lerning) для забезпечення сучасних вимог бізнесу. Але зауважимо, що електронна освіта сьогодні не може бути обмежена електронними версіями друкованих підручників i електронними тестами. Поняття електронної освіти - це насамперед якісний методичний матеріал, навчальний контент, регламентований «Положенням про електронні освітні ресурси» і затверджений наказом Міністерства освіти і науки, молоді та спорту України від 01.10.2012 p. № 1060 (останні зміни і доповнення датовано 22.12.2017p.) [2].

Діджиталізація освіти, розвиток ІКТ, вимоги до якості сучасного навчального контенту сприяє появі попиту серед освітян на оволодіння сучасними комп'ютерними технологіями і роботи з програмним забезпеченням для створення нових електронних навчальних матеріалів.

Якщо мова йде про електронний навчальний контент, відразу спадають на думку навчальні презентації, відеоролики, електронні посібники, комп'ютерне тестування і як цілісний продукт - електронний навчальний курс. У роботі «Засоби e-learning в організації роботи 3 теоретичним контентом 3 технічних дисциплін» наведено таблицю «Вибір носія теоретичного матеріалу», де перераховано категорії, основні функції носія навчальної інформації і форми (вид) носія навчальної інформації. Саме форми носіїв навчальної інформації досі ускладнюють створення навчальних курсів, якісних навчальних відео, обробку зображень, інтегрування мультимедійних матеріалів в електронні курси, використання під час змішаного освітнього процесу.

У роботі Г. Ткачук, присвяченій змішаному навчанню, сказано про міжнародні проєкти, які працюють над впровадженням змішаного навчання, серед яких Comenius 2.1, Erasmus + «Curriculum for Blended Learning», Online4EDU, Horizon Project. Зокрема, роботу проєктів скеровано на впровадження в освітній процес нових засобів IКТ, створення електронних ресурсів для забезпечення освітнього процесу різними методиками навчання та розробки інноваційних навчальних програм з усіх освітніх напрямів. 


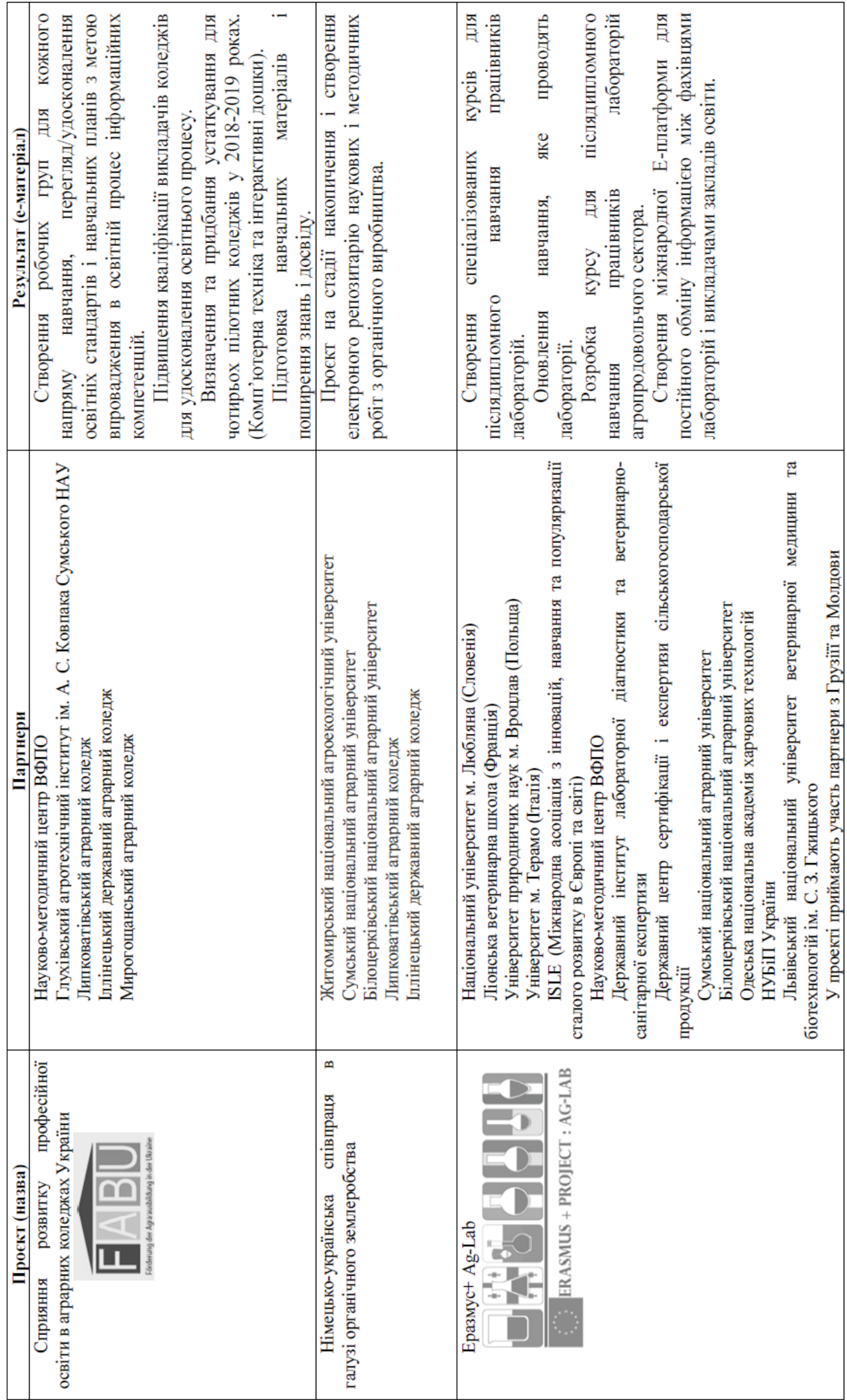


Головним поштовхом для запровадження нових форм навчання $\epsilon$ процес глобальної інформатизації та комп'ютеризації суспільства, які затребували під час підготовки фахівців формування цифрових компетентностей, запровадження у робочих процесах різноманітних інновацій. Слід відзначити Університет центральної Флориди (США), який розпочав запроваджувати елементи дистанційного навчання у 1990-х роках, визначивши основну мету такої технології навчання - підвищення якості освіти, гнучкість і доступність курсів і більш раціональне використання грошових внесків та матеріально-технічних ресурсів. Аналіз досліджень, проведений у Стенфордському університеті, підтвердив ефективність використання елементів дистанційного навчання 3 використання електронних навчальних матеріалів у поєднанні 3 традиційними методами. Результатом досвіду 3 впровадження дистанційних форм навчання став відомий сьогодні проєкт Coursera - електронна платформа, що пропонує сотні безкоштовних онлайн-курсів [8].

Варто відзначити гнучку модель навчання в Європі, яка поєднує різні форми дистанційного навчання і спрямована на індивідуальний підхід до кожного (Flex Model) [9].

Сьогодні Україна і деякі інші країни беруть участь у проєкті Erasmus + «Curriculum for Blended Learning» [10]. Одним із напрямів роботи проєкту є впровадження сучасних ІКТ i електронних елементів навчання в освітні процеси закладів освіти різних рівнів.

У своїй роботі Д. Топоров зазначає, що діджиталізація освітнього процесу найбільш помітна в професійній освіті через максимальну наближеність до практики. Професійні школи здебільшого залежать від технологічних і економічних перетворень, зумовлених цифровою революцією. Повсякчасне впровадження діджиталізації на виробничих процесах провокує зміщення трудового навантаження від традиційної форми в бік обробки і аналізу інформації. Також автор зазначає, що в останні десятиліття європейська освіта фокусує на конструюванні знань шляхом обробки інформації, і завдяки мобільним технологіям та інтернету, на думку автора, такий підхід призводить до зміни форм освітнього процесу та співпраці між викладачем і студентом у здобутті знань [5, с. 109-116].

У виступі керівника проєкту FABU «Сприяння розвитку професійної аграрної освіти в аграрних коледжах України» Х. Г. Хассенпфлюга зазначено: «Діджиталізація - це перетворення аналогової інформації або процесів у цифровий зручний формат».[6] Дослідник наголошує, що однією з актуальних сфер застосування діджиталізації є освіта та підвищення кваліфікації, перепідготовка кадрів, дорадництво. Постійний розвиток аграрних технологій вимагає від освітнього середовища динамічних змін для забезпечення виробничих потреб в якісних фахівцях, водночас обсяг нових знань та інформації щороку збільшуються, що ускладнює якісну підготовку у рамках традиційних форм навчання. Тому реформування традиційних форм навчання аграрної освіти сьогодні має враховувати необхідність індивідуалізації, самовідповідальності, здібностей і навчальних потреб студентів, орієнтацію на вирішення реальних завдань, самооцінювання. Названі характеристики ЗВО не в змозі забезпечити якісно, тож потрібно спрямувати освітній процес в бік практичної підготовки i застосування цифрових технологій. У найпростішому розумінні використання цифрових технологій можна представити як доступ до електронних навчальних матеріалів, специфічної довідникової інформації та електронних навчальних курсів.

Розширюючи застосування цифрових технологій, можна говорити про технології віртуальної і доповненої реальності, які сьогодні використовують для віртуального моніторингу врожаїв, керування обладнанням, передбачення погодних умов. Цікавим прикладом роботи є додаток «plant vision», який використовує технології доповненої реальності та штучного інтелекту. Використовуючи інфрачервоний спектр, додаток «PV» виявляє захворювання рослин у тепличних умовах на ранніх стадіях (рис. 2). 


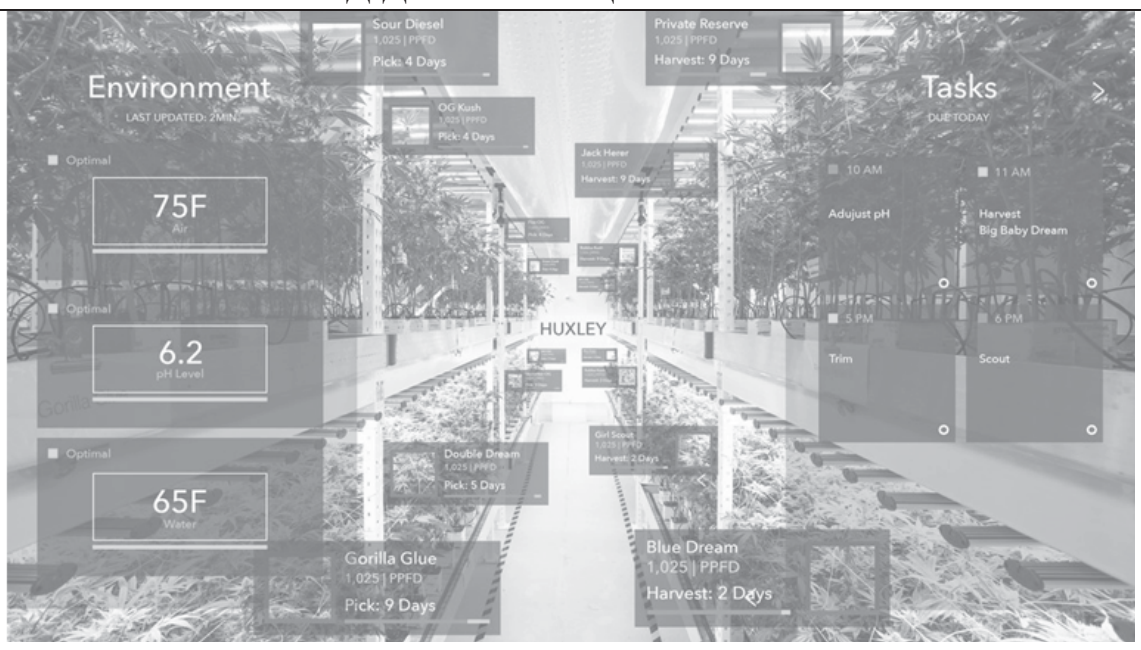

Рис. 2. Приклад роботи додатка «plant vision»

Цей додаток покликаний допомогти малим фермерським господарствам, в яких суттєво відчувається брак фахівців з агрономії, а в переважній більшості випадків такі господарства просто не можуть фінансово собі дозволити такого фахівця.

Серед напрямів роботи проєкту Erasmus $+\epsilon$ «Сapacity Building - підготовка фахівців 3 напряму лабораторної справи для аграрного сектору. До проєкту залучено університети, кожний з яких реалізує підготовку фахівців на рівні магістра відповідно до свого профілю. Білоцерківський НАУ і ЛНУВМтаБТ імені С. Гжицького реалізують проєкт у сфері ветеринарної медицини, Сумський НАУ - за напрямом агрономія, НУБіП України тваринництво, Одеська національна академія харчових технологій - харчові технології.

Важливим елементом роботи зазначеного проєкту є створення веб-порталу, де будуть розміщені сучасні електронні підручники, створені у співпраці університетів, це - теоретична складова, і двох вітчизняних лабораторій - практична складова: «Державний науководослідний інститут з лабораторної діагностики та ветеринарно-санітарної експертизи» i «Державний центр сертифікації і експертизи сільськогосподарської продукції». Станом на перший квартал 2019 р. проведено плідну роботу над підручниками і веб-порталом, створено навчальні відеоматеріали тощо, саму платформу презентовано у квітні 2019 року в Ліоні на засіданні координаційного комітету.

Варто зазначити про плани щодо створення електронної платформи знань для органічного сільського господарства в Україні, окреслені в рамках проєкту «Німецькоукраі $\square$ нська співпраця в галузі органічного землеробства». Метою проєкту є поліпшення освіти та підвищення кваліфікації фахівців і керівників підприємств у галузі органічного землеробства України. Проєкт діє з 2016 р., в січні 2019 р. було проведено зустріч-нараду 3 залученням представників Державної установи «Науково-методичний центр вищої та фахової передвищої освіти» (ДУ НМЦ «Агроосвіта»), Житомирського НАУ, Федерації органічного руху України та інших організацій, що займаються органічним виробництвом. Метою зустрічі було визначення стану освітньої складової органічного виробництва, концеції електронної платформи, матеріалів для наповнення і шляхів реалізації ключових тем роботи проєкту:

- поліпшення якості продукції органічного виробництва завдяки переданню практичних знань;

- підвищення фахової компетенції викладачів аграрних професійних шкіл та університетів, а також консультантів у галузі органічного землеробства;

-передання необхідної інформації співробітникам регіональних органів аграрного управління;

- підвищення компетенції Міністерства розвитку економіки, торгівлі та сільського господарства України щодо підтримки й регулювання органічного виробництва.

Підготовка $з$ органічного виробництва є дисципліною, яку викладають за вибором. Під час наради було представлено дані, що сьогодні підготовкою фахівців аграрного профілю 3 елементами органічного виробництва займаються 11 ЗВО серед яких 5 коледжів. 
Як результат роботи було визначено технічні сторони реалізації електронної платформи, які передбачають чотири взаємозв'язані елементи (рис. 4), завдання яких - реалізувати наведену структурну схему «Електронна платформа знань з органічного виробництва» (рис. 3).

\begin{tabular}{|c|c|}
\hline 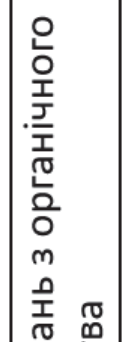 & $\begin{array}{c}\text { Освітня частина } \\
\text { Наукові публікації, статті } \\
\text { Навчальні посібники, підручники } \\
\text { Мультимедійні навчальні матеріали } \\
\text { Онлайн-курси і вебінари } \\
\text { Методичні матеріали } \\
\text { Конференції, семінари, тренінги }\end{array}$ \\
\hline 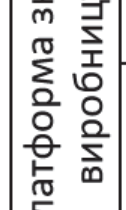 & $\begin{array}{c}\text { Бізнесова складова } \\
\text { Навігаційна карта господарств з інформацією про діяльність } \\
\text { Консультаційні центри } \\
\text { Сертифікація } \\
\end{array}$ \\
\hline 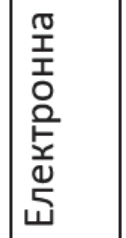 & $\begin{array}{c}\text { Загальні елементи } \\
\text { Новини ринку органічного виробництва } \\
\text { База нормативно-правових та законодавчих документів } \\
\text { Календар подій } \\
\text { Перше знайомство }\end{array}$ \\
\hline
\end{tabular}

Рис. 3. Структурна схема «Електронної платформи знань з органічного виробництва».

Розглянемо більш детально схему, наведену на рис. 4. Керуючий сайт - головний елемент платформи, який комунікує між собою елементи платформи i реалізує бізнесову та комунікаційну функцію між зацікавленими і задіяними учасниками ринку послуг з органічного виробництва. Передбачений функціонал можливо реалізувати, застосувавши популярні системи управління контентом (CMS).

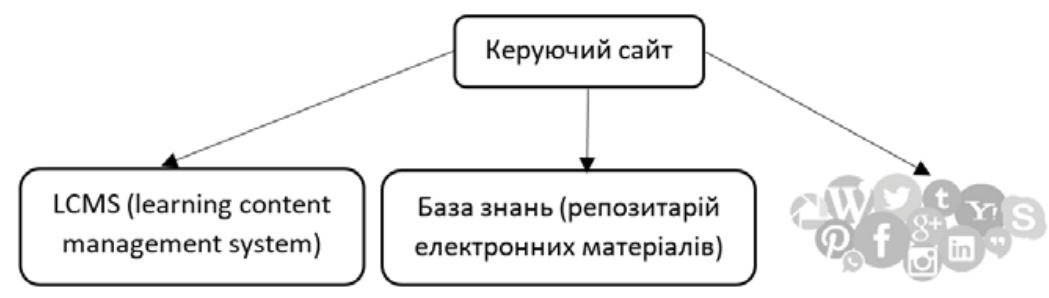

Рис. 4. Концептуальна схема електронної платформи знань.

Існують сайти організацій, які реалізовують комунікаційну функцію, надаючи актуальну інформацію 3 органічного виробництва для представників бізнесу, науки і освіти. Сайти представляють інтереси бізнесу, освіти і науки в сфері органічного виробництва в Україні, але освітню складову можна розширити запровадженням електронних навчальних курсів, адже ефективне органічне виробництво - це широкопрофільний процес і потребує залучення фахівців не тільки аграрного профілю.

На основі викладеного доходимо висновку, що, зважаючи на зростаючий інтерес до органічного виробництва, постала необхідність забезпечення освітнього і наукового попиту, що реалізувати на звичайному сайті неможливо. Тому наступним логічним кроком $є$ залучення до роботи керуючого сайту LCMS (learning content management system) для забезпечення освітнього процесу у різних формах (змішане навчання, дистанційне для самоосвіти, підвищення кваліфікації тощо) і використання бази знань, а саме репозитарію, де в електронній формі можна накопичувати науковий і методичний досвід. 
Наповнення електронної платформи знань - питання, яке виходить на перший план, оскільки електронна платформа є динамічним освітнім елементом, який одразу має реакцію на освітні тенденції, а це - перехід від «пасивного» навчання до «активного», персоналізація навчання, збільшення практичної складової освітнього процесу, навчання, основане на компетенціях.

Створення сучасних електронних навчальних матеріалів в українському освітньому середовищі сьогодні дуже актуальне. МОН України анонсувало створення Національної освітньої електронної платформи. Нині про повноцінну електронну освіту в Україні ще говорити зарано, але це великий крок на шляху розвитку вітчизняної освіти.

Робота міжнародних освітніх проєктів сьогодні допомагає українській професійній освіті набувати міжнародний досвід і впроваджувати його в освіту, економіку і виробництво нашої країни. Адже продуктивність людської праці має свою межу і розвиток будь-якої сфери людської діяльності можливий за умови вдосконалення і впровадження новітніх технологій, передовсім, за рахунок підготовки фахівців, готових до використання і реалізації сучасних технологій. Серед результатів роботи проєктів необхідно зазначити: удосконалення освітніх стандартів і навчальних планів, впровадження в освітній процес ІКТ компетенцій; підвищення кваліфікації викладачів 3ВО; визначення та придбання устатковання для коледжів-учасників проєктів; підготовка сучасних навчальних матеріалів, поширення знань і передового досвіду. Враховуючи позитивний досвід участі українських аграрних коледжів в міжнародних проєктах, доцільно ставити завдання про генерування ідей для реалізації в рамках вже існуючих проєктів або брати участь у конкурсах та грантах на фінансування нових освітніх проєктів. Долучення до роботи в міжнародних освітніх проєктах відкриває можливості для усіх учасників i насамперед для молодого покоління, яке отримає сучасну якісну освіту і має можливість реалізувати себе як затребуваного фахівця. Освітня спільнота отримує досвід, що вирішить проблеми невідповідності застарілих методів викладання і підготовки молодих фахівців вимогам ринку праці та невідповідності технічного устатковання ЗВО сучасним освітнім тенденціям і глобальній діджиталізації.

\section{ЛІТЕРАТУРА}

1. Дигіталізація як сучасна тенденція розвитку інституту освіти: Матеріали I Міжнародної наукової конференції ІКС-2012, Львів, 25-28 квітня 2012 р. - Львів: Вид-во «НУ Львівська політехніка», 2012. $-384 \mathrm{c}$.

2. Про затвердження Положення про електронні освітні ресурси: наказ Міністерство освіти і науки, молоді та спорту України від 01.10.2012 № 1060 Дата оновлення: № 749 29.05.2019. URL: https://zakon.rada.gov.ua/laws/show/z1695-12

3. Результати роботи проекту // Інтернет-сайт. - 2018. [Електронний ресурс] - Режим доступу: http://agrarausbildung-ukraine.net/projekt/?lang=uk

4. Силадій І. Розвиток освіти в контексті основних викликів глобалізації / І. Силадій // Вища освіта України. - 2016.-№ 4 - С. 34-38.

5. Топоров Д. А. Дигитализация образования: за и против, перспективы / Д. А. Топоров // Сравнительная педагогика. - 2018. - № 8. - С. 109-116.

6. Цифрові технології в сільському господарстві - поточний стан та значення для освіти : матеріали V міжнародної наукової конференції [Цифрова освіта у природничих університетах], (Київ, 17-18 жовт. 2018 р.). - К.: НУБіП України, 2018. - 148 с.

7. EACEA; Eurydice; Eurostat. Key Data on Education in Europe 2012 / EACEA; Eurydice; Eurostat // Brussels: Eurydice. - 2012. [Електронний ресурс] - Режим доступу: http://www.saaic.sk/eurydice/publikacie/Key\%20Data\%20on\%20 Education\%202012\%20\%20Final\%20Report.pdf

8. Insights and Trends that Make MOOCs Matter. URL: https://www.edsurge.com/news/2014-08-04insights-and-trends-that-make-moocs-matter.

9. Laine S., Myllymäki M., Hakala I. The Role of the Learning Styles in Blended Learning // EDULEARN15 Proceedings. 7th International Conference on Education and New Learning Technologies (Barcelona,6th-8th of July 2015). Barcelona, 2015. PP. 5016-5025.

10. Transnational Needs Analysis Report. URL: http://blearning-project.eu/index.php/news/18-transnationalneeds-analysis-report. 


\title{
REFERENCES
}

1. Digitization as a modern tendency of development of the Institute of Education: Proceedings of the 1st International Scientific Conference of IKS-2012, Lviv, April 25-28, 2012 - L'viv: Issue «NU L'vivs'ka politekhnika», 2012. - 384 p.

2. On Approval of the Regulation on Electronic Educational Resources: Order of the Ministry of Education and Science, Youth and Sports of Ukraine from 10.10.2012 № 1060 Date of updating: \# 749 29.05.2019. URL: https://zakon.rada.gov.ua/laws/show/z1695-12.

3. Project results // Website. - 2018. [Electronic resource] - Access mode: http://agrarausbildungukraine.net/projekt/?lang=uk.

4. Syladiy I. Development of education in the context of the main challenges of globalization / I. Syladiy // Vyshcha osvita Ukrayiny. - 2016. \# 4 - S. 34-38.

5. Toporov D. A. Digitalization of education: pros and cons, prospects / D. A. Toporov. // Sravnytel'naya pedahohyka. - 2018. - \# 8. - S. 109-116.

6. Digital technologies in agriculture - current status and importance for education: materials of the 5th International Scientific Conference ["Digital Education in Natural Sciences"], (Kyyiv, October 17-18, 2018) / MES of Ukraine, NUBiP Ukrayiny, Wroclawski University of Natural Sciences. - Kyyiv : NUBiP Ukrayiny, 2018. - $148 \mathrm{p}$.

7. EACEA; Eurydice; Eurostat. Key Data on Education in Europe 2012 / EACEA; Eurydice; Eurostat // Brussels: Eurydice. - 2012. [Elektronnyy resurs] - Rezhym dostupu: http://www.saaic.sk/eurydice/publikacie/Key\%20Data\%20on\%20 Education\%202012\%20\%20Final\%20Report.pdf.

8. Insights and Trends that Make MOOCs Matter. URL: https://www.edsurge.com/news/2014-08-04insights-and-trends-that-make-moocs-matter.

9. Laine S., Myllymäki M., Hakala I. The Role of the Learning Styles in Blended Learning // EDULEARN15 Proceedings. 7th International Conference on Education and New Learning Technologies (Barcelona,6th-8th of July 2015). Barcelona, 2015. PP. 5016-5025.

10. Transnational Needs Analysis Report. URL: http://blearning-project.eu/index.php/news/18-transnationalneeds-analysis-report.

Стаття надійшла в редакиію 28.11.2019 p.

УДК:37.013.3;378.016

DOI 10.25128/2415-3605.19.2.17

ЮРІЙ СОКОТОВ

https://orcid.org/0000-0002-8654-5882 juriy2104@gmail.com асистент

Тернопільський національний педагогічний університет ім. В. Гнатюка

м. Тернопіль, вул. Максима Кривоноса, 2

\section{КОМП'ЮТЕРНЕ КОНСТРУЮВАННЯ МЕБЛЕВИХ ВИРОБІВ ЯК ПРОФЕСІЙНА ПОСЛУГА МАЙБУТНЬОГО ДЕРЕВООБРОБНИКА}

\begin{abstract}
Розкрито зміст комп'ютерного проектування меблевих виробів як професійної послуги майбутнього деревообробника. Охарактеризовано три способи здійснення проектування: ручний, автоматизований та автоматичний. Виокремлено як основний спосіб проектування автоматизований, реалізачію якого забезпечують САПР. Обтрунтувано критерії вибору оптимальної САПР меблевого виробництва. Встановлено, щзо комп'ютерне конструювання меблевих виробів, як майбутня професійна послуга деревообробника, несе в собі сутність дизайнерської діяльності з проектування (іноді створення) естетичних і функиіональних речей на основі єдності художнього, наукового і технічного підходів. Визначено основний зміст дизайнерської діяльності з проектування меблів, що закладено у функиіональні можливості САПР. Реалізацію етапів проектування меблів здійснено у програмному середовищі PRO 100. Комп'ютерне проектування меблевих виробів може відбуватися з дотриманням визначених підходів щеодо розробки послуг: підхід «офіс/майстерня», підхід «покупеиь як робоча сила», підхід «гнучка робоча сила». Для перевірки ефективності комп'ютерного конструювання меблевих виробів як професійної послуги майбутнього деревообробника було проведено дослідноекспериментальну роботу за основу якої взято модель цінності послуги. Цінність послуги оцінювалася
\end{abstract}

